\title{
Synthesis and biological evaluation of potential positron emission tomography (PET) ligands for brain visualization of dopamine $\mathrm{D}_{3}$ receptors
}

\author{
Enza Lacivita, Francesco Berardi, Nicola A. Colabufo, Marcello Leopoldo, Roberto \\ Perrone, and Vincenzo Tortorella
}

Università degli Studi di Bari, Dipartimento Farmaco-Chimico, via Orabona, 4, 70125 Bari, Italy

E-mail: lacivita@farmchim.uniba.it

\begin{abstract}
Currently, the lack of a selective dopamine $\mathrm{D}_{3}$ PET (positron emission tomography) radioligand for in vivo brain occupancy studies is problematic. Several requirements are necessary for a potential PET radioligand for visualization of a receptor into the brain: i) high affinity and selectivity for the target receptor; ii) suitable lipophilicity for both blood-brain barrier permeation and low nonspecific binding to proteins and lipids; iii) structural features that allow labelling with a positron emission isotope. In this study the synthesis and binding affinities for dopamine $\mathrm{D}_{3}$ and $\mathrm{D}_{2}$ receptors of several $N$-[4-(4-arylpiperazin-1-yl)butyl]arylcarboxamides are reported. These compounds were designed by the structural modification of the formerly reported $\mathrm{D}_{3}$ receptor ligand $\quad N$-[4-[4-(2,3-dichlorophenyl)piperazin-1-yl]butyl]-7-methoxy-2benzofurancarboxamide (1), with the aim to obtain a suitable lipophilicity and the structural features for labelling. In particular, both the 2,3-dichlorophenyl group and the 7-methoxy-2benzofurancarboxamide moiety were replaced by less lipophilic fragments. Among the studied compounds, derivatives $\quad N$-[4-[4-(5-methoxy-2-benzisoxazolyl)piperazin-1-yl]butyl]-4-(4morpholinyl)benzamide (20), $N$-[4-[4-(5-methoxy-2-benzisoxazolyl)piperazin-1-yl]butyl]-4-(1Himidazol-1-yl)benzamide (21), and $N$-[4-[4-(5-methoxy-2-benzisoxazolyl)piperazin-1-yl]butyl]5-(2-furanyl)-1H-pyrazole-3-carboxamide (22) displayed good $\mathrm{D}_{3}$ receptor affinities ( $K_{\mathrm{i}}$ values 38 , 22.6, and $21.3 \mathrm{nM}$, respectively) and were found to be inactive at $\mathrm{D}_{2}$ receptor. Moreover, on the basis of their experimental $\log \mathrm{P}$ values and their ability to cross the Caco-2 monolayer, compounds 20-22 are likely to permeate the blood-brain barrier, differently from compound $\mathbf{1}$.
\end{abstract}

Keywords: Dopamine, $\mathrm{D}_{3}$ receptors, PET, lipophilicity, blood-brain barrier, arylpiperazines 


\section{Introduction}

Recent studies have suggested that the dopamine $\mathrm{D}_{3}$ receptor, a member of the $\mathrm{D}_{2}$-like receptor family, is a promising therapeutic target for a variety of conditions including drug abuse, restless legs syndrome, schizophrenia, Parkinson's disease, and depression. Potent and selective $\mathrm{D}_{3}$ ligands has been proposed as therapeutic agents for the treatment of these conditions. ${ }^{1-5}$

Positron Emission Tomography (PET) is a sensitive and specific neuroimaging technology for quantitative measurement of in vivo density of cerebral receptors. Moreover, PET is a powerful tool for the study of normal and pathological brain function and diseases and for drug development research. PET imaging requires an appropriate radioligand labeled with a positronemitting isotope.

In order to develop a tracer for a receptor in the central nervous system a number of demands have to be met. ${ }^{6}$ First of all, the tracer needs to have high affinity and selectivity (about 100-fold) for the target receptor. Although the affinity is an important factor to achieve a high signal to noise ratio, also the lipophilicity of the tracer is relevant. The lipophilicity should not be too high in order to avoid nonspecific binding to protein and lipids. On the other hand, an optimal lipophilicity ( $\log \mathrm{P}$ near 2 ) of drugs is required for good blood-brain barrier permeability. ${ }^{7}$ Therefore, it appears that there is an optimal range of lipophilicity for brain radioligands, wherein brain uptake is high and nonspecific binding comparatively weak. Frequently, the selection of a candidate PET radioligand has been done on the basis of the affinity value and selectivity, leading to poor results when lipophilicity of the candidate was high. From literature data a value of $\log \mathrm{P}=3.5$ appears to be the acceptable upper limit of lipophilicity for a PET radioligand. ${ }^{8}$ Finally, an important consideration is that the radiolabeling of a potent ligand may lead to a new chemical entity with a different pharmacological profile as compared to the original compound. Therefore, it would be preferrable the optimization of compounds with structural features that allow labeling leading to a radioligand that is undistinguishable, from a physiological point of view, from its unlabeled counterpart.

To date, the lack of a selective dopamine $\mathrm{D}_{3}$ PET radioligand is problematic, due to a lack of suitable radioligands. A limited number of radioligand has been prepared and validation studies are in progress. ${ }^{9-11}$ The aim of the present study is to identify a $\mathrm{D}_{3}$ receptor ligand as a potential PET radioligand, taking into account all the above mentioned requirements in an early stage of development. Therefore, we have designed compounds displaying the structural features that are necessary for binding at $\mathrm{D}_{3}$ receptors, having a $\mathrm{Clog}^{12}$ (calculated $\log \mathrm{P}$ ) value between 2 and 3.5, and a methoxy group in the structure that can give an easy access to labelling with the positron emitter isotope ${ }^{11} \mathrm{C}$.

In a previous paper, we have published a structure-affinity relationship study on $\mathrm{N}$-[4-(4arylpiperazin-1-yl)butyl]arylcarboxamides as potent and selective dopamine $\mathrm{D}_{3}$ receptor ligands. ${ }^{13}$ The highest $\mathrm{D}_{3}$ receptor affinity values were obtained when the aryl substituent linked to the $\mathrm{N}-1$ of the piperazine ring was the 2,3-dichlorophenyl and the arylcarboxamide moiety was an aromatic bicyclic system. Among the studied compounds, derivative 1 (Table 1) showed 
some features of a potential PET radioligand: high $\mathrm{D}_{3}$ receptor affinity, high selectivity over $\mathrm{D}_{2}$ receptor, and the presence of a methoxy group. However, compound $\mathbf{1}$ displayed high lipophilicity ( $\operatorname{Clog} \mathrm{P}=4.98)$ that might have led to a high non-specific binding. In a recent paper Newman and co-workers have pointed out that the high lipophilicity of dopamine $\mathrm{D}_{3}$ ligands could represent a limit concerning their bioavailability. Therefore, they studied some arylcarboxamides, structurally related to the prototypical antagonist NGB 2904 (Chart 1), specifically designed to obtain compounds with reduced lipophilicity. In particular, the 2quinoxalinocarboxamide 2 and the 4-(2-pyridyl)benzamide 3 showed the lowest ClogP values (4.48 and 4.86, respectively). ${ }^{14}$ Although compounds 2 and 3 displayed lower lipophilicity than NGB-2904 (ClogP= 6.04), their lipophilicity was still high.

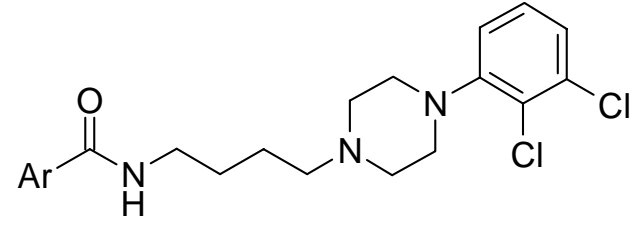

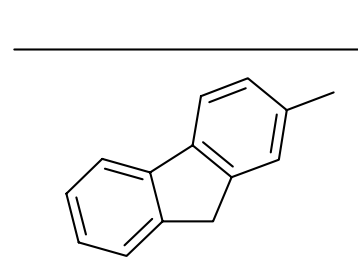

NGB-2904 (ClogP = 6.04)

$\operatorname{Ar}$

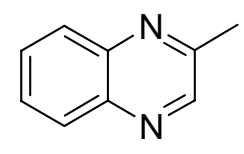

$2(\mathrm{C} \log \mathrm{P}=4.48)$<smiles>Cc1ccc(-c2ccccn2)cc1</smiles>

$3(\mathrm{Clog} P=4.86)$

\section{Chart 1}

Therefore, based on these findings, in order to obtain compounds endowed with lower lipophilicity, we replaced the 2,3-dichlorophenyl ring in compound $\mathbf{1}$ with a heteroaromatic bicyclic ring (derivatives 6-11, Table 1), and the 2-methoxyphenyl group (compound 12). As shown in Table 1, this first modification fulfilled the goal of lowering lipophilicity, but it was detrimental for $\mathrm{D}_{3}$ receptor affinity. Therefore, a second set of compounds was prepared by replacing the 7-methoxy-2-benzofurane ring of compounds $\mathbf{6}$ and $\mathbf{1 2}$ with a 2-naphthalene-like or a 1,4-biphenyl-like ring systems in order to increase the $\mathrm{D}_{3}$ affinity and further lower lipophilicity (compounds 16-22, Table 2 and compounds 25-31, Table 3).

\section{Chemistry}

The studied compounds were synthesized as depicted in Schemes 1-3. 


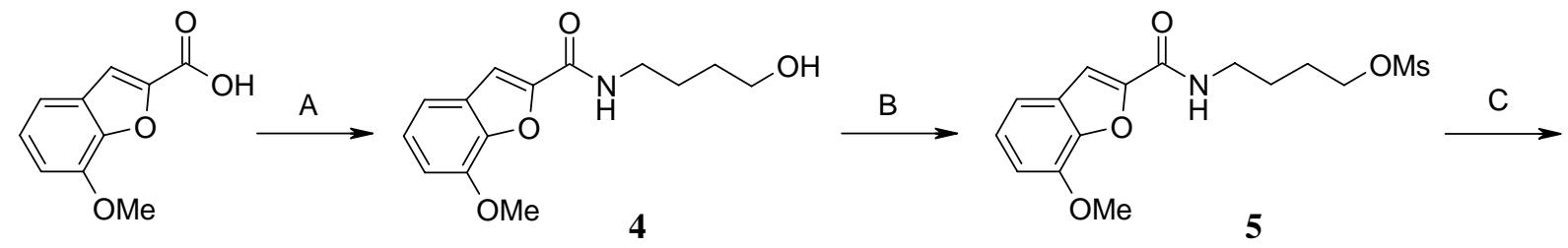<smiles>COc1cccc2cc(C(=O)NCCCCN3CCN([Al])CC3)oc12</smiles>

Scheme 2. Reagents: (A) i: $\mathrm{SO}_{2} \mathrm{Cl}$; ii: 4-amino-1-butanol; (B) $\mathrm{Et}_{3} \mathrm{~N}, \mathrm{CH}_{3} \mathrm{SO}_{2} \mathrm{Cl}$; (C) 1arylpiperazine.
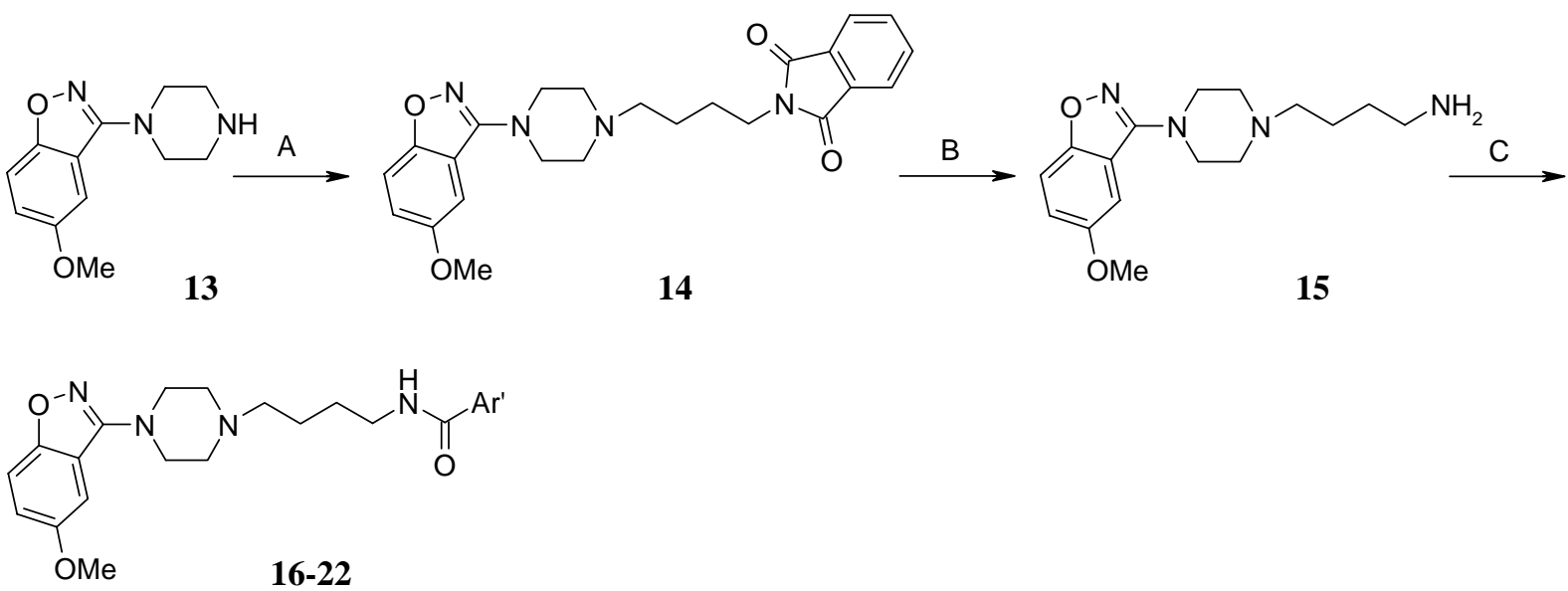

Scheme 2. Reagents: (A) 4-Bromobutylphatilimide; (B) i: $\mathrm{NH}_{2} \mathrm{NH}_{2}$, ii: $\mathrm{HCl}$, conc.; (C) aryl carboxylic acid, 1'1-carbonyl diimidazole.<smiles>COc1ccccc1N1CCN(c2ccccc2OC)CC1</smiles><smiles>COc1ccccc1N1CCN(CCCCNC(=O)[AlH2])CC1</smiles>

Scheme 3. Reagents: (A) 4-Bromobutyronitrile; (B) i: borane methyl sulfide complex; (C) aryl carboxylic acid, 1'1-carbonyl diimidazole. 


\section{Results and Discussion}

The first set of compounds (Table 1) originated from 1 by replacing the 2,3-dichlorophenyl with a byciclic ring. As shown by the affinity data reported in Table 1, this modification of $\mathbf{1}$ was detrimental for $\mathrm{D}_{3}$ receptor affinity. In fact, derivatives $\mathbf{6 , 8}, \mathbf{1 0}$, and 11 retained only moderate $\mathrm{D}_{3}$ affinity values, whereas compounds 7 and $\mathbf{9}$ were devoid of $\mathrm{D}_{3}$ receptor affinity. The orientation of the bicyclic ring seems of great importance in the interaction with the $\mathrm{D}_{3}$ receptor. In fact, $\mathbf{6}$ and $\mathbf{8}$ still retained $\mathrm{D}_{3}$ receptor affinity, whereas their corresponding isomers $\mathbf{7}$ and $\mathbf{9}$ were devoid of $D_{3}$ receptor affinity. The 2-methoxyphenyl derivative 12 showed the highest $D_{3}$ affinity within this group of compounds.

Table 1. Binding affinity and ClogP values

12

\footnotetext{
${ }^{a}$ Binding experiments were performed using human recombinant $\mathrm{D}_{3}$ receptor expressed in $\mathrm{CHO}$ cell line and $\left[{ }^{3} \mathrm{H}\right]-$ spiroperidol. ${ }^{b}$ Binding experiments were performed using human recombinant $\mathrm{D}_{2}$ receptor expressed in rat C6 glioma cell line and $\left[{ }^{3} \mathrm{H}\right]$-spiroperidol. ${ }^{c}$ Values calculated using ClogP 4.0 (version for Windows), BioByte Corp., Claremont, CA. ${ }^{d}$ Full $K_{\mathrm{i}}$ not obtained, percentage inhibition at the concentration shown given in parentheses.
} 
At this point, other structural modifications were necessary to achieve compounds with enhanced $\mathrm{D}_{3}$ receptor affinity values. With this aim, we replaced the 7-methoxy-2-benzofuranyl ring with a 2-naphthalene-like or a 1,4-biphenyl-like ring systems, because these types of ring systems were proved to be tolerate in $\mathrm{D}_{3}$ receptor binding. This modification was effected on compounds 6 and 12 because they showed a good compromise between $\mathrm{D}_{3}$ receptor affinity, selectivity, and lipophilicity. The binding affinity data of compounds 16-22, structurally related to 6, (Table 2) indicated that 1,4-biphenyl-like rings in the carboxamide moiety were tolerated better than 2-naphthalene-like rings in the interaction with dopamine $\mathrm{D}_{3}$ receptor. In fact, carboxamides 20-22 were more potent than 6, whereas compounds 16,18 , and 19 showed $\mathrm{D}_{3}$ receptor affinity in the same range of $\mathbf{6}$. Derivative $\mathbf{1 7}$ was devoid of $\mathrm{D}_{3}$ receptor affinity. As far as the affinity for $\mathrm{D}_{2}$ receptor is concerned, compounds 16-22 were found inactive.

Table 2. Binding affinity and ClogP values

21

${ }^{a-d}$ See the corresponding footnotes in Table 1. 
Considering the compounds $\mathbf{2 5 - 3 1}$ (Table 3) that are structurally related to $\mathbf{1 2}$, it can be noted that all compounds displayed $\mathrm{D}_{3}$ receptor affinities in the same range as $\mathbf{1 2}$. Moreover, differently from the 1,2-benzisoxazolyl derivatives, within the 2-methoxyphenyl series there was no difference in $\mathrm{D}_{3}$ receptor affinity between the carboxamides with a 2-naphthalene-like ring or a 1,4-biphenyl-like ring. 2-Methoxyphenyl derivatives 25-31 showed higher $\mathrm{D}_{3}$ affinities than their counterparts $\mathbf{1 6}-\mathbf{2 2}$, but proved to be poorly selective over $\mathrm{D}_{2}$ receptors.

Table 3. Binding affinity and ClogP values<smiles>COc1ccccc1N1CCN(CCCCNC(=O)Br)CC1</smiles>

\begin{tabular}{|c|c|c|c|c|}
\hline & \multicolumn{4}{|c|}{$K_{\mathrm{i}}, \mathrm{nM}$} \\
\hline Compd. & Ar' & $\mathrm{D}_{3}{ }^{a}$ & $\mathrm{D}_{2}^{b}$ & $C \log \mathrm{P}^{c}$ \\
\hline 25 & & $77.9 \pm 42$ & $179 \pm 20$ & 2.40 \\
\hline 26 & & $60.1 \pm 4.5$ & $146 \pm 25$ & 2.66 \\
\hline 27 & & $14.7 \pm 3.4$ & $86.2 \pm 6.5$ & 2.38 \\
\hline 28 & & $58.5 \pm 9.2$ & $>1000(47 \%)^{d}$ & 3.02 \\
\hline 29 & & $23.9 \pm 1.5$ & $141 \pm 30$ & 2.62 \\
\hline 30 & & $4.79 \pm 0.18$ & $27.2 \pm 7.3$ & 2.55 \\
\hline 31 & & $19.3 \pm 0.9$ & $130 \pm 15$ & 3.06 \\
\hline
\end{tabular}

${ }^{a-d}$ See the corresponding footnotes in Table 1 .

Taken together these results indicated that a significant lowering in lipophilicity of our reference compound 1 can be achieved by replacing the 2,3-dichlorophenyl ring. However, this structural feature is essential for high $\mathrm{D}_{3}$ receptor affinity. By contrast, replacement of the 7methoxybenzofurane ring with less lipophilic fragments might lead to an increasing in the affinity for $\mathrm{D}_{3}$ receptor. 
Derivatives 20-22, which showed the best in vitro affinity profile among all the new compounds, were further studied. Experimental logP of compounds 20-22 were obtained by the pH metric technique. ${ }^{15,16}$ All compounds showed logP values well within the range that we had chosen, although experimental values were slightly different from the calculated values (20: $\log \mathrm{P}=3.16 ; 21: \log \mathrm{P}=2.63 ; 22: \log \mathrm{P}=2.98)$.

The potential ability of compounds 1 , and 20-22 to cross the blood-brain barrier was evaluated in vitro by permeation studies with human colon carcinoma cell line (Caco-2). ${ }^{17}$ This assay revealed that only 20-22 were able to cross the cell monolayer, whereas compound $\mathbf{1}$ was not. In fact, the $\mathrm{P}_{\text {app }}$ (apparent permeability) values obtained were: 1 : not detectable $\left(<1 \bullet 10^{-6} \mathrm{~cm}\right.$ $\mathrm{sec}^{-1}$ ); 20: $36.3 \pm 0.11 \cdot 10^{-6} \mathrm{~cm} \mathrm{sec}^{-1}$; 21: 6.56 $\pm 0.96 \cdot 10^{-6} \mathrm{~cm} \mathrm{sec}^{-1}$; 22: $7.39 \pm 0.74 \cdot 10^{-6} \mathrm{~cm} \mathrm{sec}^{-1}$.

In this study we have proposed a new strategy to design potential PET radioligand specifically for the visualization of brain dopamine $\mathrm{D}_{3}$ receptors. We have performed structural modification on the high affinity $\mathrm{D}_{3}$ receptor ligand $N$-[4-[4-(2,3-dichlorophenyl)piperazin-1yl]butyl]-7-methoxy-2-benzofurancarboxamide (1), in order to lower lipophilicity within a optimal range and still retaining good $\mathrm{D}_{3}$ receptor affinity. A significant reduction in lipophilicity was achieved mainly by substituiting the 2,3-dichlorophenyl group. Among the studied compounds, derivatives 20-22 displayed good $\mathrm{D}_{3}$ receptor affinities $\left(K_{\mathrm{i}}\right.$ values ranging from 21.3 $\mathrm{nM}$ and $38 \mathrm{nM}$ ) and were selective over $\mathrm{D}_{2}$ receptor. Moreover, on the basis of their experimental $\log \mathrm{P}$ values and their ability to cross the Caco-2 monolayer, compounds 20-22 are likely to permeate the blood-brain barrier, differently from compound 1. Therefore, they represent a good starting point for a further development.

\section{References}

1. Joyce, J. N. Pharmacol. Ther. 2001, 90, 231.

2. Pilla, M.; Perachon, S.; Sautel, F.; Garrido, F.; Mann, A.; Wermuth, C. G.; Schwartz, J. C Everitt, B. J.; Sokoloff, P. Nature 1999, 400, 371.

3. Heidbreder, C. A.; Gardner, E. L.; Xi, Z.-X.; Thanos, P. K.; Mugnaini, M.; Hagan, J. J.; Ashby, C. R. Brain Res. Rev. 2005, 49, 77.

4. Levant, B. Pharmacol. Rev. 1997, 49, 231.

5. Biglan, K. M.; Holloway, R. G. Expert Opin. Pharmacother. 2002, 3, 197.

6. Halldin, C.; Gulyás, B.; Langer, O.; Farde, L. Q. J. Nucl. Med. 2001, 45, 139.

7. Hansch, C.; Bjorkroth, J. P.; Leo, A. J. Pharm. Sci. 1987, 76, 663.

8. de Paulis, T. Curr. Pharm. Des. 2003, 9, 673.

9. de Vries, E. F. J.; Elsinga, P. H.; van Waarde, A.; Kortekaas, R.; Dijkstra, D.; Vaalburg, W. J. Label. Compd. Radiopharm. 2003, 46, S140.

10. Tu, Z.; Huang, Y.; Vangveravong, S.; Blair, j. B.; Luedtke, R. R.; Dence, C.; Mach, R. H. J. Label. Compd. Radiopharm. 2003, 46, S179. 
11. Sovago, J.; Farde, L.; Halldin, C.; Langer, O.; Laszlovszky, I.; Kiss, B.; Gulyas, B. Neurochem. Int. 2004, 45, 609.

12. ClogP 4.0 (version for Windows), BioByte Corp., Claremont, CA.

13. Leopoldo, M.; Berardi, F.; Colabufo, N. A.; De Giorgio, P.; Lacivita, E.; Perrone, R.; Tortorella, V. J. Med. Chem. 2002, 45, 5727.

14. Newman, A. H.; Cao, J.; Bennett, C. J.; Robarge, M. J.; Freeman, R. A.; Luedtke, R. R. Bioorg. Med. Chem. Lett. 2003, 13, 2179.

15. Comer, J. E.; Tam, K. Y. In Pharmacokinetic Optimization in Drug Research; Testa, B.; van de Waterbeemd, H., Folkers, G.; Guy, R. H.; Eds.; Wiley-VCH: Zürich, 2001; pp 275-304.

16. Avdeef, A. In Lipophilicity in Drug Action and Toxicology; Pilska, V.; Testa, B.; van de Waterbeemd, H., Eds.; VCH Publishers: Weinheim, 1996; pp 109-139.

17. Artursson, P.; Karlsson, J. Biochem. Biophys. Res. Comm. 1991, 175, 880. 